Article

\title{
Selecting the Best Version of SHALOM to Assess Spiritual Well-Being
}

\author{
John Fisher ${ }^{1,2}$ \\ 1 Faculty of Education \& Arts, Federation University Australia, Ballarat, Victoria 3350, Australia; \\ j.fisher@federation.edu.au; Tel.: +61-438-395-915 \\ 2 Department of Rural Health, Faculty of Medicine, Dentistry \& Health Sciences, University of Melbourne, \\ Victoria 3010, Australia; jwfisher@unimelb.edu.au
}

Academic Editor: Arndt Büssing

Received: 1 March 2016; Accepted: 27 April 2016; Published: 30 April 2016

\begin{abstract}
This paper extends the reporting of contemporary use of the Spiritual Health and Life-Orientation Measure (SHALOM), which provides flexibility to researchers, enabling them to choose the version of the instrument that best suits the cohort under investigation. SHALOM was built on a solid theoretical foundation, provided by the Four Domains Model of Spiritual Health/Well-Being. It comprises 20 items that assess spiritual well-being, as reflected in the quality of relationships that each person has with themselves, others, the environment, and/or with God. Summary results are reported from 30 recent studies. SHALOM provides a unique form of assessment that is statistically stronger than just assessing lived experiences, in that spiritual harmony/dissonance is studied by comparing each person's "lived experiences" with her/his "ideals" for spiritual well-being. SHALOM has been sought for use with hundreds of studies in 29 languages, in education, healthcare and wider community. A generic form of SHALOM was developed to expand the Transcendental domain to include more than God. However, recent studies have shown that relating with God is most important for spiritual well-being. The best version of SHALOM to assess spiritual well-being depends on the needs of the clients/participants and the project goals of the researcher. This will involve a selection between the original form of Spiritual Well-Being Questionnaire-SHALOM for comparison with other measures and investigation of characteristics influencing spiritual well-being; or the dissonance method for spiritual care; and either the original or the generic version of SHALOM for use with non-religious/secular participants.
\end{abstract}

Keywords: spiritual well-being; assess; SHALOM; God

\section{Introduction}

Many, if not most, papers about it say that, "Spirituality is hard, if not impossible, to define." It is difficult to declare the exact meaning or scope of spirituality. However, that is also the case for concepts such as "love" and "beauty", but people still use these terms as if they agree on what they mean. With spirituality, people have attempted to describe its properties in various ways, including outlining the historical contexts in which the term has been used [1], epistemologically [2,3], or by type [4].

When the positive psychological construct of well-being is added to spiritual aspects of humanity, there is potential for greater confusion. However, the National Interfaith Coalition on Aging's (NICA) framework definition of spiritual well-being (SWB), as "the affirmation of life in a relationship with God, self, community and environment that nurtures and celebrates wholeness" [5], was supported by an intensive qualitative study, which provided an expanded description of spiritual health as:

A, if not the, fundamental dimension of people's overall health and well-being, permeating and integrating all the other dimensions of health (i.e., physical, mental, emotional, social and vocational). 
Spiritual health is a dynamic state of being, shown by the extent to which people live in harmony within relationships in up to four domains of spiritual well-being:

Personal domain - wherein one intra-relates with oneself with regards to meaning, purpose and values in life.

Communal domain - as shown in the quality and depth of interpersonal relationships, relating to morality, culture and religion.

Environmental domain - beyond care and nurture for the physical and biological, to a sense of awe and wonder, for some, the notion of unity, with the environment.

Transcendental domain-relationship of self with some-Thing or some-One beyond the human level (i.e., ultimate concern, cosmic force, transcendent reality, or God) [6].

This description of SWB in four domains encompasses the vast majority of components of SWB mentioned in contemporary literature, which has expanded exponentially over the last two decades [7].

It is one thing to describe spirituality, but another to measure it. Moberg [8], and Koenig [9], have raised concerns about measuring spirituality in research projects. Judicious selection of an appropriate instrument is needed. With the increasing interest in spirituality and well-being, especially over the last 30 years, numerous quantitative surveys have been developed to investigate this area [10-13]. Quantitative survey is an accepted and sound research method to be employed in this area [14-18].

Expanding on a previous report of spirituality measures [19], the Four Domains Model of SWB provided a theoretical foundation to critique 260 available measures of spirituality and well-being [20]. This compendium of multi-item measures is organised by year of development within three types of spirituality measures, namely (i) spiritual health/well-being measures; (ii) spirituality measures; and (iii) related/partial spirituality measures, for four sections of studies (i) of a General nature; (ii) in University only; (iii) in Schools (with youth); and (iv) Health settings. The advice of Zwingmann et al. needs to be heeded in selecting instruments for studies in spirituality. As well as "measurement intentions and item wording ... psychometric properties, length of the instruments, and the possibility for comparisons with prior studies" need to be considered [21]. The 260 instruments mentioned were described by composition of items within the four domains of spirituality, plus religious items and "others". Comment was made regarding the status of each instrument with respect to Factor Analysis. The number and type of people in each study were reported together with place (country) in which each study was performed. The first author was named to readily access the reference list, with the final column providing information regarding the source through which to retrieve a copy of each instrument.

Of available measures used to assess spirituality, recent comments have reported that the Spiritual Well-Being Questionnaire (SWBQ)-SHALOM (Spiritual Health and Life-Orientation Measure) is well-accepted ([22,23]; [24], p. 41). The survey design, content, style of responses and statistical analysis employed in SWBQ-SHALOM are consistent with standard quantitative research methodology. National and international studies have shown the suitability of SHALOM for research in SWB in a variety of settings and languages [25]. A summary of this research has spawned considerable interest, being downloaded 10,069 times from the time of its publication in December 2010 to March 2016.

\section{Development of SHALOM (the Spiritual Health and Life-Orientation Measure)}

The history of the development of SHALOM has been detailed previously [25-27]. The 20-item SHALOM comprises five items in each of four factors that investigate the quality of relationships that people have with themselves, with others, with the environment, and/or with a Transcendent Other (most often called God). The items chosen for the personal SWB were "a sense of identity, self-awareness, joy in life, inner peace and meaning in life"; those for the Communal SWB were "love of other people, forgiveness toward others, trust between individuals, respect for others, kindness toward other people"; Environmental SWB investigated "connection with nature, awe at a breathtaking view, oneness with nature, harmony with the environment, sense of 'magic' in the environment"; Transcendental SWB inspected "personal relationship with the Divine/God, worship of the Creator, 
oneness with God, peace with God, prayer life." Responses are given on a 5-point Likert scale from $1=$ very low to $5=$ very high. Exploratory factor analyses strongly supported the four domains of SWB, which also cohered into a single higher-order factor labelled spiritual well-being [27].

SHALOM is actually two instruments in one. Two responses per item were gleaned for the Spiritual Health measure (which assesses "lived experience") And the Life-Orientation Measure (which assesses "ideals" for spiritual well-being). The difference between the ideals and lived experience scores was used to investigate the level of spiritual harmony/dissonance, as a basis for pastoral care.

Before SHALOM was developed, all but one of reported quantitative SWB studies had been undertaken with adults and older youth, who were mainly in universities. Apart from the desire to produce a spiritual health/well-being measure for use with young people, it was asserted that development of a measure that had language that was meaningful to young people should also be useful for a wide range of adults. Subsequent studies with secondary school students, together with university students and church attenders were used to show that the SWBQ, the lived experience sector of SHALOM, had good reliability, with Cronbach's alpha, composite reliability and variance extracted. The SWBQ also has good construct, concurrent, discriminant and predictive validity, and also shows factorial independence from personality [27]. Further analyses revealed "general support for the psychometric properties of the SWBQ from an Item Response Theory (IRT) perspective" [28], making this instrument the first of only three spiritual well-being questionnaires to report IRT $[29,30]$. "Multi-group factor analysis also [showed] gender equivalencies for the SWBQ" [31].

\section{Applications of the SWBQ-SHALOM}

Since its development in 1999, the SWBQ-SHALOM has been sought for use in hundreds of studies in 29 languages. However, only a minority of those requests have so far resulted in publications from completed projects, many of which are still in the planning and data-gathering stages. The best of intentions can also be way-laid for a variety of reasons, including changes in priorities or employment during the project; lack of funding or other support for the project; inclement health by researcher or family member; political influence such as "separation of church and state" in the USA; search for culturally-specific content. Using such specific measures has disadvantages in that the results cannot be compared with those in other groups. Moberg has emphasised the need to "combine particularistic and universal strategies for clinical assessments and scientific research in SWB" [14].

The SWBQ-SHALOM is a measure that has shown its general applicability in a wide range of settings. Summary findings have previously been reported from 28 projects, which employed the original 20-item form of SHALOM, and from another three that used variations on the original. Several studies were mentioned there in which only total scores for SWB, not the individual factor scores, were used [25]. Findings from another 30 recent studies using the complete measure are listed in Table 1.

Table 1. Spiritual well-being (SWB) levels from recent studies using the Spiritual Well-Being Questionnaire-Spiritual Health and Life-Orientation Measure (SWBQ-SHALOM).

\begin{tabular}{|c|c|c|c|c|c|c|c|c|c|c|c|}
\hline \multirow[b]{3}{*}{ Ref } & \multirow{3}{*}{$\begin{array}{l}\text { Schools } \\
\text { Sample }\end{array}$} & \multirow[b]{3}{*}{ Country } & \multirow[b]{3}{*}{$\mathbf{n}$} & \multicolumn{8}{|c|}{ Four Domains of SWB } \\
\hline & & & & \multicolumn{2}{|c|}{ PER } & \multicolumn{2}{|c|}{ COM } & \multicolumn{2}{|c|}{ ENV } & \multicolumn{2}{|c|}{ TRA } \\
\hline & & & & $x$ & SD & $x$ & SD & $x$ & SD & $x$ & SD \\
\hline \multicolumn{12}{|c|}{ students } \\
\hline [32] & Sec Anglican Female & UK & 228 & 4.00 & 0.86 & 4.24 & 0.72 & 3.19 & 0.97 & 2.73 & 1.26 \\
\hline [33] & Secondary & Spain & 114 & 3.75 & 0.80 & 3.82 & 0.69 & 3.18 & 0.92 & 2.65 & 1.17 \\
\hline \multirow[t]{3}{*}[34]{} & Sec nonreligious & Hong Kong & 305 & 3.53 & 0.80 & 3.59 & 0.78 & 3.00 & 0.85 & 2.51 & 1.05 \\
\hline & Religious school1 & & 341 & 3.73 & 0.65 & 3.75 & 0.63 & 3.25 & 0.75 & 3.09 & 1.01 \\
\hline & Religious school2 & & 409 & 3.57 & 0.71 & 3.66 & 0.67 & 3.18 & 0.71 & 2.72 & 1.06 \\
\hline [35] & Secondary & Hong Kong & 14828 & 3.54 & 0.78 & 3.64 & 0.76 & 3.10 & 0.85 & 2.71 & 1.03 \\
\hline [36] & Secondary & Australia & 114 & 3.86 & 0.68 & 4.12 & 0.56 & 3.54 & 0.85 & 3.14 & 0.97 \\
\hline
\end{tabular}


Table 1. Cont.

\begin{tabular}{|c|c|c|c|c|c|c|c|c|c|c|c|}
\hline & & & & \multicolumn{8}{|c|}{ Four Domains of SWB } \\
\hline \multicolumn{3}{|c|}{ UNIVERSITY } & & \multicolumn{2}{|c|}{ PER } & \multicolumn{2}{|c|}{ COM } & \multicolumn{2}{|c|}{ ENV } & \multicolumn{2}{|c|}{ TRA } \\
\hline Ref & Sample & Country & $\mathbf{n}$ & $x$ & SD & $x$ & SD & $x$ & SD & $x$ & SD \\
\hline [37] & AOG Liberal Arts & USA & 375 & 3.94 & 0.54 & 4.08 & 0.66 & 3.06 & 0.91 & 3.82 & 0.91 \\
\hline [38] & Nurse education & Indonesia & 105 & 4.09 & 0.67 & 4.04 & 0.73 & 3.92 & 0.78 & 4.20 & 0.73 \\
\hline \multirow{2}{*}{ [39] } & \multirow{2}{*}{ Teacher ed. students } & Hong Kong & 573 & 3.95 & 0.64 & 4.05 & 0.60 & 3.46 & 0.71 & 2.95 & 1.11 \\
\hline & & Australia & 557 & 4.06 & 0.67 & 4.28 & 0.60 & 3.26 & 0.83 & 2.56 & 1.12 \\
\hline \multirow[t]{2}{*}{ [40] } & RE students & Turkey & 137 & 4.22 & 0.77 & 4.31 & 0.62 & 4.07 & 0.81 & 4.43 & 0.75 \\
\hline & Divinity students & & 122 & 4.03 & 0.79 & 4.05 & 0.72 & 3.88 & 0.76 & 4.22 & 0.77 \\
\hline [33] & Ed Psych students & Spain & 151 & 4.29 & 0.61 & 4.21 & 0.56 & 3.51 & 0.89 & 2.26 & 1.15 \\
\hline \multirow[t]{2}{*}[41]{} & Psych students & UK & 101 & 3.75 & 0.81 & 3.87 & 0.71 & 3.01 & 1.02 & 2.35 & 1.30 \\
\hline & & & & \multicolumn{8}{|c|}{ Four Domains of SWB } \\
\hline & Health & & & \multicolumn{2}{|c|}{ PER } & \multicolumn{2}{|c|}{ COM } & \multicolumn{2}{|c|}{ ENV } & \multicolumn{2}{|c|}{ TRA } \\
\hline Ref & Sample & Country & $\mathbf{n}$ & $x$ & SD & $x$ & SD & $x$ & SD & $x$ & SD \\
\hline \multirow[t]{2}{*}{ [42] } & Nurses of dementia pts & Australia & 21 & 4.51 & 0.60 & 4.60 & 0.52 & 4.01 & 0.86 & 3.44 & 1.21 \\
\hline & Family & & 23 & 3.69 & 0.77 & 4.25 & 0.66 & 3.64 & 0.95 & 3.62 & 0.89 \\
\hline [43] & Nurses & USA & 33 & 3.98 & & 3.95 & & 3.15 & & 4.03 & \\
\hline$[44]$ & Cancer patients & Portugal & 169 & 3.10 & 0.84 & 3.47 & 0.57 & 3.25 & 0.97 & 3.66 & 0.92 \\
\hline [45] & Renal patients & UK & 72 & 2.43 & 1.16 & 2.37 & 1.08 & 2.39 & 1.10 & 2.40 & 1.18 \\
\hline$[46]$ & Organ donor & Israel & 312 & 3.92 & 0.63 & 3.99 & 0.58 & 3.43 & 0.86 & 1.99 & 1.11 \\
\hline [47] & Nurses & Israel & $260 *$ & 4.06 & & 4.04 & & 2.84 & & 3.38 & \\
\hline$[48]$ & Medical sciences & Iran & 157 & 4.43 & 0.73 & 4.31 & 0.69 & 4.17 & 0.76 & 4.58 & 0.73 \\
\hline \multicolumn{12}{|c|}{ Church } \\
\hline [49] & Chinese immigrants & Ireland & 68 & 3.65 & 0.63 & 3.80 & 0.72 & 3.33 & 0.67 & 3.66 & 0.69 \\
\hline$[50]$ & Religious sisters & Indonesia & 186 & 4.14 & 0.52 & 4.13 & 0.44 & 4.10 & 0.48 & 4.46 & 0.44 \\
\hline [51] & Buddhist chaplains & USA & 48 & 3.16 & 0.82 & 3.66 & 0.65 & 3.41 & 0.91 & 2.58 & 1.27 \\
\hline [52] & Religious sisters & Vietnam & 271 & 3.89 & 0.58 & 3.72 & 0.57 & 3.59 & 0.65 & 4.12 & 0.64 \\
\hline \multicolumn{12}{|c|}{ Business } \\
\hline [53] & Home economists & International & 66 & 4.03 & 0.85 & 4.05 & 0.75 & 3.50 & 1.04 & 2.93 & 1.25 \\
\hline$[54]$ & Public Corporation & Puerto Rico & 265 & 4.58 & 0.66 & 4.36 & 0.74 & 3.92 & 0.95 & 4.33 & 0.96 \\
\hline \multicolumn{12}{|c|}{ Community } \\
\hline [55] & Community & Portugal & 439 & 3.77 & 0.58 & 3.72 & 0.54 & 3.56 & 0.74 & 2.90 & 0.96 \\
\hline$[56]$ & Physical Activity & Portugal & 342 & 3.80 & 0.62 & 3.82 & 0.57 & 3.67 & 0.74 & 3.12 & 0.87 \\
\hline [57] & Elderly & Portugal & 52 & 2.99 & 1.11 & 3.44 & 0.84 & 3.62 & 0.84 & 3.19 & 0.99 \\
\hline$[58]$ & Consumers & Australia & 1011 & 3.54 & 0.79 & 3.64 & 0.73 & 3.15 & 0.87 & 2.65 & 1.26 \\
\hline [59] & Public & UK & $43 *$ & 3.53 & & 3.83 & & 3.17 & & 1.61 & \\
\hline [60] & Public & Portugal & 320 & 3.60 & 0.66 & 3.71 & 0.58 & 3.41 & 0.74 & 2.71 & 1.01 \\
\hline
\end{tabular}

A cursory inspection of means between the two batches of results using SHALOM showed:

For School students-comparable values for each domain across the two samples, with variations on Transcendental SWB by religious affiliation, but students' scores were lower than those reported by school staff.

For University students-the more religious students in the second batch scored higher on Environmental and Transcendental SWB.

In Health settings, providers scored higher than patients on each domain.

In Churches-it was not surprising to note that those in religious orders scored higher on Transcendental SWB than church attenders.

In Business-there appears to be a marked cultural variation, with people from Puerto Rico outscoring others on each domain of SWB.

In Community—domestic violence victims from South Africa reported a stronger relationship with God (Transcendental SWB) than did others.

\section{Alternative Versions of the $S W B Q$}

SHALOM was built on the four domains model of spiritual health/well-being from which twelve items were selected to represent each domain, being reduced to the five items with highest item-total correlation. No instrument can give an absolute measure of SWB. However, in order to check the consistency, or otherwise, of responses using different items, a second set of five items per domain 
were extracted from the same cohort as for the original SHALOM to form another psychometrically sound measure called SWBQ2 [61]. As their items varied, it was not surprising to find that the factor scores varied between SHALOM and SWBQ2 for Personal, Communal and Environmental SWB, but not the Transcendental domain, due to positive and negative variations between schools cancelling each other on this factor (see Table 2).

An additional alternative version of the SWBQ-SHALOM employed a scale score from 1 to 6 [24]. Two further researchers only used selected items from the total 20-item instrument $[62,63]$ and one more used the total score instead of factor scores [64].

Table 2. Alternate versions of the SWBQ-SHALOM used to assess SWB.

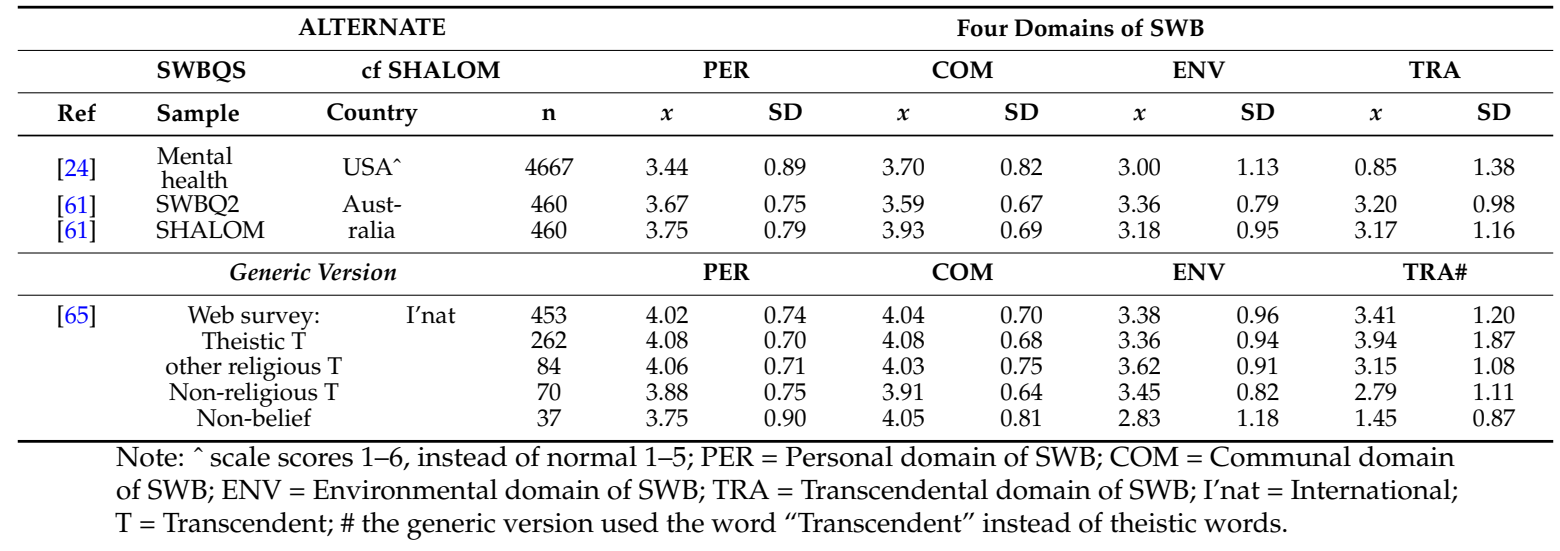

The above results show that using different scale scores or adding, subtracting, or modifying any of the five items in each of the four domains of SHALOM yields different instruments, results from which cannot be compared with other studies using the original SHALOM, with its 20 items and 5-point Likert scale. They should therefore be given different names.

\section{Generic Version of SHALOM}

At conferences, three people made comments that SHALOM was too God-oriented, even though the word was only mentioned in three of the twenty items in SHALOM, in contrast to, for example, the ten times in the 20 items in the Spiritual Well Being Survey [66]. It appears that what these people were really saying is that they would only be happy with no reference to God, in accord with their world-view. This limited view of the world does not fit with most Western civilisations, where census data show that a majority of the populace claim adherence to God-based religions [67]. Traditional Western views of spirituality arose from religious studies, especially in the Catholic Church [68].

Many authors concur with Seaward's view, "Although spirituality and religion are separate but related concepts that often overlap, it is inconceivable to separate the concept of spirituality from the divine aspect of the universe" ([69], p. 77). That notwithstanding, in light of the claim of theistic bias levelled at the existing SHALOM, four of the five original Transcendental factor items had the words "God", "Divine" and "Creator" replaced by the word "Transcendent". In the revised version, respondents were presented with the statement, "When people believe their lives are influenced by SomeOne or SomeThing beyond the human and natural worlds, they use different words". To effect the instruction for participants to "Please choose one of the following to show what best describes the supernatural influence in your life", eighteen alternatives were provided, namely "Allah, Angel/s, Buddha, Deceased person, Deity/deities, Divine, Fate, Father God, Gaia, God, Heaven, Higher power, Higher self, Mystery, Otherness, Presence, Something there, Universe/ universal spirit," or respondents could indicate "Not an area in which I believe" (see results in Table 2). The "Tao" was inadvertently omitted from the list, although no respondents in that study indicated Taoism as their preferred religion/world-view from 26 alternatives provided. Tao has now been added to the generic version of SHALOM. 
Confirmatory factor analyses revealed that the modified, generic form of SHALOM showed acceptable model fit, comprising four clearly delineated domains of spiritual well-being. Of particular interest was the finding that the modified Transcendental domain of spiritual well-being holds together well statistically and provides the greatest explanation of variance in spiritual well-being overall [65,70], as has been shown with the original version of SHALOM [61,71,72] and in a junior spiritual well-being questionnaire called "Feeling Good, Living Life" [73]. Those respondents who indicated relating with God as their Transcendent revealed that this relationship enhances relationships with themselves and other people more strongly than that done by alternative religious or non-religious Transcendents, or none [65]. This study and others have shown that relating with God is most important for spiritual well-being [61,71,72]. Thus, it appears that NICA correctly listed God first in their description of SWB [5]. It is also interesting to note that ninety per cent of 260 available multi-item measures of spirituality/well-being reported items assessing relationship with God [20]. It is important to note that removal of God from any study would leave only humanistic, existential well-being. For example, this would be the case if the ten items on Religious well-being (querying relationship with God) were removed from the Spiritual Well-Being Survey then only ten items on Existential well-being would remain [66]. It is valid then to question whether any study that deletes God is truly a measure of spiritual well-being.

Although some words have been changed in it (see Section 3 above), the modified SHALOM can be employed in future studies as a generic measure of spiritual well-being across a variety of worldviews, because the inherent structure of the instrument remains intact. However, the nature of the cohort under investigation should determine which version of SHALOM is used, not the world-view of the investigators.

\section{Spiritual Harmony/Dissonance}

Almost all available spirituality/well-being measures [20] only seek a single response to indicate respondents' level of lived experience on items/factors investigated by the nominated scales. Instruments developed by Fisher $[26,65,74]$ use a novel technique, in that they compare each person's "lived experience" with their "ideals" for spiritual well-being. In other words, each person becomes the standard against which they are measured, rather than being compared or grouped by using some arbitrary norm. The difference between the "ideals" and "lived experience" score indicates the level of harmony or dissonance in each domain. This is a fairer approach of assessing spiritual well-being because each person is allowed to view each term in light of their own understanding of it, rather than having their view compared with someone else's.

Analyses have shown that using dissonance scores for each of the 20 items in SHALOM actually provides a statistically stronger instrument than just using the "lived experience" scores, as is done in other spirituality measures [61]. The dissonance technique thus provides a better measure of quality of relationships in the four domains, which reflect spiritual well-being. An application of this technique, in a recent web survey using SHALOM, revealed that "spiritual harmony shared the strongest relationship with mental health when compared to any other variable used in this study" ([24], p. 84). This finding applied equally well to the religious and secular participants in that study. Dissonance, referred to as "spiritual incongruence", was found to be a significant predictor of burnout among Buddhist chaplains [51].

Dissonance scores generated using SHALOM can provide carers with insight into their clients' spiritual well-being in the four domains assessed. For example, secondary school students with large dissonance scored lower on the Oxford Happiness Inventory, higher on psychoticism (assessed using the Junior Eysenck Personality Questionnaire-Revised), and reported less help from God, parents and self for developing spiritual well-being. As teachers and religious leaders were not implicated in the lower levels of help, they need to be aware of the supporters who are, in order to aid the holistic development of their students [75]. Such insights can be invaluable to carers such as teachers, chaplains and those in aged and palliative care. However, these spiritual nurturers need appropriate training and 
experience in this area to become aware of their clients' needs and to adequately help their clients, as previous studies have shown that carers' lived experience influences how well they provide spiritual care $[76,77]$.

\section{Truncated Version of SHALOM?}

A few researchers are looking for quick and easy ways to assess spiritual health/well-being. Considerable effort has recently been expended investigating 26 studies that have employed the full 20-item version of SHALOM, with a total of 30,514 participants, to see if SHALOM could be reduced in size, whilst maintaining its integrity.

Item-total correlations were inspected for the five items in each of the four domains comprising SHALOM. At the outset, it needs to be noted that each of the items showed large $(>0.5)$ correlational values in each factor, within the 26 studies for which full data were available.

In the Personal domain, the two items which consistently showed highest item-total correlational values were "inner peace" and "joy in life" followed closely by "meaning in life". Although "a sense of identity" and "self-awareness" trailed the field equally, they were still statistically strong items in this domain. Theoretically, according to the Four Domains model of SH/SWB, these latter two items are key elements of relationship with oneself.

In the Communal domain, the two items that consistently showed highest correlational values were "kindness towards other people" and "respect for others", with "trust between individuals" a close third, followed by "forgiveness towards others" and "a love of other people". All were still statistically strong items in this domain. Forgiveness and love are also strong features, which theoretically reflect quality of relationships with other people.

In the Environmental domain, the three items with highest correlational values were "oneness with nature", "connection with nature" and "harmony with the environment", followed by "a sense of 'magic' in the environment" and "awe at a breathtaking view". Once again, all were still statistically strong items in this domain. The wording of the first three items was sufficiently similar to yield strong correlations. The last two items reflected different aspects of relationship with the environment.

In the Transcendental domain, the three items with highest correlational values were "oneness with God", "peace with God" and "worship of the Creator", followed closely by "personal relationship with the Divine/God" and "prayer life". All were remarkably strong statistically, with average item-total correlation values exceeding 0.9 . The last two items are theoretically paramount in terms of relationship with God.

Exploratory factor analyses were performed to test the underlying structure of each of the four factors, beginning with the 5-item sets, reducing to 3, then 2. The Kaiser-Meyer-Olkin (KMO) test of sampling adequacy requires 0.6 as a minimum for good factor analysis [78]. The 5-item factors showed highest KMO values, all at 0.80 and above (shown in bold in Table 3), whereas the 3-item factors were weaker, especially in the Personal and Communal factors, with KMO values less than 0.7 (see Table 3 ). The 2-item "factors" were completely inadequate with KMO values of only 0.5 .

Table 3. Sampling adequacy for 5- and 3-item versions of SHALOM.

\begin{tabular}{ccccccccc}
\hline \multirow{2}{*}{ SHALOM } & \multicolumn{2}{c}{ PER } & \multicolumn{2}{c}{ COM } & \multicolumn{2}{c}{ ENV } & \multicolumn{2}{c}{ TRA } \\
\cline { 2 - 9 } & KMO & \%var & KMO & \%var & KMO & \%var & KMO & \%var \\
\hline 5-item & $\mathbf{0 . 8 0}$ & 58 & $\mathbf{0 . 8 3}$ & 60 & $\mathbf{0 . 8 3}$ & 63 & $\mathbf{0 . 8 9}$ & 80 \\
3-item & 0.69 & 68 & 0.68 & 70 & 0.72 & 75 & 0.74 & 83 \\
\hline
\end{tabular}

Note: $\mathrm{KMO}$ = Kaiser-Meyer-Olkin values of sampling adequacy; \%var = \% variance explained.

Retention of the three items with highest item-total correlations for each factor yielded an improved percentage of variance explained, which would be expected. More importantly, however, lower KMO values, indicating less favourable measures, resulted from deletion of two items per factor. 
The significant loss in perspective regarding spiritual health/well-being that would be attained does not warrant removal of any of these items. In effect, saving approximately two to three minutes in completion of the questionnaire would markedly reduce the depth of understanding revealed by respondents' perspectives and life experiences related to spiritual well-being. Conclusion, "Take the extra time. It is definitely worth it!" Justice cannot be done to a complex construct such as SH/WB by attempting to assess it with a few, or even a handful of, items [20].

\section{Limitations}

While many of the studies provided results of exploratory factor analyses and some alpha values for factors, only a small number reported confirmatory factor analyses [35,37,56,61]. It would be beneficial if each study that used SHALOM provided results of confirmatory factor analyses to further validate this instrument in the wide range of settings and countries in which it is being used. This would provide additional confidence for other researchers comparing results from their studies with those reported here and previously [25].

\section{Conclusions}

Spiritual well-being is a complex issue which cannot be adequately addressed in a few words, nor can it be adequately assessed using instruments with only a few items. This paper has reviewed the contemporary use of a 20-item spiritual well-being questionnaire called SHALOM. Although it must be stressed that 20 items cannot provide an exhaustive assessment of spiritual well-being, this instrument has been shown to be a sound statistical measure within a variety of age groups in a good range of nations.

The "lived experience" component of SHALOM can be favourably compared with other standard measures of spirituality/well-being, although SHALOM differs from them in that it uses the same number of items in each of its four domains, thus not privileging any one domain over the others. As a growing number of studies are reporting their findings using SHALOM, it is becoming increasingly useful as a database upon which to compare other studies using a single-response technique.

However, SHALOM uses the unique double-response technique of comparing each person's "lived experience" with their "ideals" for SWB. This a fairer approach to assessing spiritual well-being as it has been shown that the difference in scores between the "ideals" and "lived experiences", called "spiritual harmony/dissonance", provides a statistically stronger measure than using only "lived experience", which is what other measures employ. This dissonance technique is very useful for spiritual carers to gain insight into their clients' spiritual needs.

As each person is compared with themselves, in each domain, if they score low on both ideals and lived experience in any domain, they do not reveal any spiritual dissonance therein. This notion of spiritual harmony (statistical opposite of dissonance) applied equally well to religious and secular participants in a study employing the original version of SHALOM [24]. Nevertheless, a few non-religious people objected to the use of "God"-words in the Transcendental domain items. These words have been modified to provide a generic version of SHALOM, which is not quite as statistically robust as the original form. The question was also raised as to whether studies deleting God could be considered "spiritual".

In keeping with the title of this paper, the best version of SHALOM to assess spiritual well-being depends on the needs of the clients/participants and the project goals of the researcher. This will involve a selection between the original form of SWBQ-SHALOM for comparison with other measures and investigation of characteristics influencing SWB; or the dissonance method for spiritual care; and either the original or the generic version of SHALOM for use with non-religious/secular participants.

Conflicts of Interest: The author declares no conflict of interest. 


\section{Abbreviations}

The following abbreviations are used in this manuscript:

$\begin{array}{ll}\text { NICA } & \text { National Interfaith Coalition on Aging } \\ \text { SHALOM } & \text { Spiritual Health And Life-Orientation Measure } \\ \text { SH/WB } & \text { Spiritual Health/Well-Being } \\ \text { SWBQ } & \text { Spiritual Well-Being Questionnaire }\end{array}$

\section{References}

1. Walter Principe. "Toward defining Spirituality." Studies in Religion 12 (1983): 127-41.

2. Heather M. Boynton. "Children's spirituality: Epistemology and theory from various helping professions." International Journal of Children's Spirituality 16 (2011): 109-27. [CrossRef]

3. John Swinton, and Stephen Pattison. "Moving beyond clarity: Towards thin, vague, and useful understanding of spirituality in nursing care." Nursing Philosophy 11 (2010): 226-37. [CrossRef] [PubMed]

4. David O. Moberg. "Expanding Horizons for Spirituality Research." 2011. Available online: http://hirr. hartsem.edu/sociology/spirituality-research.html (accessed on 15 October 2013).

5. National Interfaith Coalition on Aging. Spiritual Well-Being: A Definition. Athens: National Interfaith Coalition on Aging, 1975.

6. John W. Fisher. "Spiritual Health: Its Nature and Place in the School Curriculum." Ph.D. Thesis, University of Melbourne, Parkville, Australia, 1998.

7. Sergei A. Kharitinov. "Religious and Spiritual Biomarkers in both Health and Disease." Religions 3 (2012): 467-97. [CrossRef]

8. David O. Moberg. "Spirituality research: Measuring the immeasurable." Perspectives on Science and Christian Faith 62 (2010): 99-114.

9. Harold G. Koenig. "Concerns about measuring 'spirituality' in research." Journal of Nervous \& Mental Diseases 196 (2008): 349-55. [CrossRef] [PubMed]

10. Peter C. Hill, and Ralph W. Hood, eds. Measures of Religiosity. Birmingham: Religious Education Press, 1999.

11. Douglas A. MacDonald, Jeffrey G. Kuentzel, and Harris L. Friedman. "A survey of measures of transpersonal constructs. Part II—Additional instruments." Journal of Transpersonal Psychology 31 (1999): 155-77.

12. Harold G. Koenig, Michael E. McCullough, and David B. Larson, eds. Handbook of Religion and Health. Oxford: Oxford University Press, 2001.

13. Bella Vivat. "Measures of spiritual issues for palliative care patients: A literature review." Palliative Medicine 22 (2008): 859-68. [CrossRef] [PubMed]

14. David O. Moberg. "Assessing and measuring spirituality: Confronting dilemmas of universal and particular evaluative criteria." Journal of Adult Development 9 (2002): 47-60. [CrossRef]

15. David O. Moberg. "Research in spirituality, religion, and aging." Journal of Gerontological Social Work 45 (2005): 11-40. [CrossRef] [PubMed]

16. Sian Cotton, Meghan O'Grady, and Susan Rosenthal. "Measurement of religiosity/spirituality in adolescent health outcomes: Trends and recommendations." Journal of Religion \& Health 49 (2010): 414-44. [CrossRef] [PubMed]

17. Harold G. Koenig. Spirituality \& Health Research: Methods, Measurement, Statistics and Resources. West Conshohocken: Templeton Press, 2011.

18. Nan Park, Beom Lee, Fei Sun, David Klemmack, Lucinda Roff, and Harold Koenig. "Typologies of religiousness/spirituality: Implications for health and well-being." Journal of Religion \& Health 52 (2013): 828-39. [CrossRef] [PubMed]

19. John Fisher. "The Four Domains Model: Connecting spirituality, health and well-being." Religions 2 (2011): 17-28. [CrossRef]

20. John W. Fisher. "A critique of quantitative measures for assessing spirituality and spiritual well-being." In Spirituality, Global Practices, Societal Attitudes and Effects on Health. Edited by Edith C. Roberts. New York: Nova Science Publishers Inc., 2015, pp. 91-131.

21. Christian Zwingmann, Constantin Klein, and Arndt Büssing. "Measuring Religiosity/Spirituality: Theoretical Differentiations and Categorization of Instruments." Religions 2 (2011): 345-57. [CrossRef] 
22. Trevor Moodley. "The Relationship between Coping and Spiritual Well-Being during Adolescence." Ph.D. Thesis, Department of Psychology, University of the Free State, Bloemfontein, South Africa, 2008.

23. Eltica Jager Meezenbroek, Bert Garssen, Machteld Berg, Dirk Dierendonck, Adriaan Visser, and Wilmar Schaufeli. "Measuring spirituality as a universal human experience: A review of spirituality questionnaires." Journal of Religion \& Health 51 (2012): 336-54. [CrossRef] [PubMed]

24. Jonathan T. Moore. "Dogmatism, coping, and spirituality: Predicting mental health among the religious and the secular." Ph.D. Thesis, University of Louisville, Louisville, KY, USA, 2013.

25. John Fisher. "Development and application of a Spiritual Well-Being Questionnaire called SHALOM." Religions 1 (2010): 105-21. [CrossRef]

26. John W. Fisher. "Developing a Spiritual Health and Life-Orientation Measure for secondary school students." In Research with a Regional/Rural Focus: Proceedings of the University of Ballarat Inaugural Annual Research Conference. Edited by Janette Ryan, Vivienne Wittwer and Peter Baird. Ballarat: University of Ballarat, Research and Graduate Studies Office, 1999, pp. 57-63.

27. Rapson Gomez, and John W. Fisher. "Domains of spiritual well-being and development and validation of the Spiritual Well-Being Questionnaire." Personality \& Individual Differences 35 (2003): 1975-91. [CrossRef]

28. Rapson Gomez, and John W. Fisher. "Item Response Theory analysis of the Spiritual Well-Being Questionnaire." Personality \& Individual Differences 38 (2005): 1107-21. [CrossRef]

29. Todd W. Hall, Steven P. Reise, and Mark G. Haviland. "An Item response Theory Analysis of the Spiritual Assessment Inventory." The International Journal for the Psychology of Religion 17 (2007): 157-78. [CrossRef]

30. Olfa Mandhouj, Jean-François Etter, Delphine Courvoisier, and Henri-Jean Aubin. "French-language version of the World Health Organization quality of life, spirituality, religiousness and personal beliefs instrument." Health and Quality of Life Outcomes. 2012, 10, pp. 39-50. Available online: http://www.hqlo.com/content/ 10/1/39 (accessed on 26 February 2015).

31. Rapson Gomez, and John W. Fisher. "The Spiritual Well-Being Questionnaire: Testing for model applicability, measurement and structural equivalencies and latent mean differences across gender." Personality $\mathcal{E}$ Individual Differences 39 (2005): 1383-93. [CrossRef]

32. Mary Hostler, e-mail text "Anglican Girls' School Spiritual Survey" to author, 7 June 2013.

33. Antonio Muñoz-García, and Maria J. Aviles-Herrera. "Effects of academic dishonesty on dimensions of spiritual well-being and satisfaction: A comparative study of secondary school and university students." Assessment E Evaluation in Higher Education 39 (2014): 349-63. [CrossRef]

34. Irene Mok. "A Study of the Spiritual Health of Adolescents in Three Hong Kong Secondary Schools." Ph.D Thesis, Hong Kong Institute of Education, Hong Kong, China, 2013.

35. Celeste Y. M. Yuen. "Gender differences in life satisfaction and spiritual health among the junior immigrant and local Hong Kong secondary students." International Journal of Children's Spirituality 20 (2015): 139-54. [CrossRef]

36. Rebecca Norwood. "Adolescent Spiritual Well-Being as a Determinant of Physical Health and Well-Being." Master's Thesis, University of Wollongong, Wollongong, Australia, 2013.

37. Patrick Malaret and Vanguard University of Southern California, e-mail text "Spiritual Well-Being of Students in a Liberal Arts College" to author, 27 March 2013.

38. Andi Sugianto. Factors Correlated with the Provision of Spiritual Care by Nursing Students. BSc Nursing Research Project; Tangerang: Universitas Pelita Harapan, 2013.

39. John W. Fisher, and Ping Ho Wong. "Comparing levels of spiritual well-being and support among pre-service teachers in Hong Kong and Australia." Religious Education Journal of Australia 29 (2013): 33-40.

40. John W. Fisher, and M. Kamil Coskun. "Investigating spiritual well-being among Divinity and Religious Education students in Turkey." Religious Education Journal of Australia 29 (2013): 21-28.

41. Emma Donohue. "Investigating the relationship between spirituality, happiness and professional psychological help-seeking behaviour." Bachelor's Thesis, University of Bolton, UK, 10 October 2015.

42. John W. Fisher. "Staff's and family members' spiritual well-being in relation to help for residents with dementia." Journal of Nursing Education \& Practice 2 (2012): 1-9. [CrossRef]

43. Carol Sykes. Spiritual Health in Nurses Practising in End-of-Life Care. Jackson: Union University, forthcoming.

44. Silvia Caldeira, Emilia G. de Carvalho, and Margarida Vieira. "Between spiritual well-being and spiritual distress: Possible related factors in elderly patients with cancer." Revista Latino-Americana de Enfermagem 22 (2014): 28-34. [CrossRef] [PubMed] 
45. Ali Ashraifeen. "Influence of Spirituality on Health Outcomes and General Well-Being in Patients with End-Stage Renal Disease." Ph.D. Thesis, University of Stirling, Stirling, UK, 2015.

46. Anat P. Bortz, Tamar Ashkenazi, and Semyon Melnikov. "Spirituality as a predictive factor for signing an Organ Donor card." Journal of Nursing Scholarship 47 (2015): 25-33. [CrossRef] [PubMed]

47. Miri Faster, Israel, e-mail text "Investigation of How Nurses' Spiritual Well-Being Relates to Their Work" to author, 25 July 2014.

48. Marzieh Nojomi, Iran University of Medical Sciences, e-mail text "Spiritual aspects of quality of life" to author, 15 April 2015.

49. Xuefei (Gabrielle) Jin. Exploring Motivations for Conversion to Christianity among Irish Chinese Immigrants and the Relationship between Religiosity and Spiritual Well-Being. Bain Theology \& Psychology Research Project; Dublin: All Hallows College, 2015.

50. Rita T. Silalahi. "Emotional Intelligence and Personality Traits on the Spiritual Well-Being of the Junior Religious Sisters in a Community." Master's Thesis, Graduate School, University of Santo Tomas, Manila, Philippines, 2014.

51. Lynette M. Monteiro. "Burnout and Spiritual Incongruence: An Evidence-Based Counselling Model for Buddhist Chaplains." Bachelor's Thesis, Upaya Zen Institute, Santa Fe, NM, USA, 2011.

52. Nguyen Bao Uyen. "Exploring the Relationship between Spiritual Well-Being and Psychological Well-Being among Religious Sisters in Vietnam." Ph.D. Thesis, De La Salle University, Manila, Philippines, 28 February 2016.

53. Jay R. Deagon. "Cross-Cultural Views and Perceptions of Spiritual Health and Well-Being in Home Economics Sites: Public Expressions and Social Enactments." Ph.D. Thesis, Griffith University, Queensland, Australia, 2014.

54. Brenda I. Sanchez. "The Perception of the SWB and Its Relationship with Optimism, Autoefficacy and Organizational Citizenship Behavior in a Workplace Sample from a Public Corporation of Puerto Rico." Ph.D. Thesis, Carlos Albizu University, San Juan, Puerto Rico, 2012.

55. Maria J. Gouveia, Marta Marques and José L. Pais Ribeiro. "Versã Portguesa do questionário de Bem-Estar Espiritual (SWBQ): Análise confirmatória da sua estrutura factorial." Psicologia, Saúde E Doenças 10 (2009): 285-93.

56. Maria J. Gouveia, José L. Pais Ribeiro, and Marta Marques. “Estudo da invariaçia do Questionário de Bem-estar spiritual (SWBQ) em praticantes de Atividades Fisicas de Inspiração Oriental." Psychology, Community \& Health 1 (2012): 140-50. [CrossRef]

57. António M. F. Veiga. "Análise Crítica da Adaptação do Instrument Shalom, a Uma Amostra de Idosos." Master's Thesis, Instituto Universitário Ciéncias Psicológicas, Sociais e da Vida, Lisbon, Portugal, 2014. Available online: http://www.rcaap.pt/detail.jsp?id=oai:repositirio.ispa.pt:10400.12/3076 (accessed on 22 February 2016).

58. Rafi Chowdhury, and Mario Fernando. "The role of spiritual well-being and materialism in determining consumers' ethical beliefs: An empirical study with Australian consumers." Journal of Business Ethics 13 (2013): 61-79. [CrossRef]

59. Eluned Mulligan, Bath, UK, e-mail text "Assessing the Concurrent Validity of the WHOQOL-SPRB Bref: A New Measure of Spiritual Quality of Life" to author, 9 May 2012.

60. Inês N. de Brito. "Relação entre o bem-estar spiritual e sintomas psicopatológicos na população adulta Portuguesa." Master's Thesis, Instituto Universitário, ISPA, Lisboa, Portugal, 2014.

61. John W. Fisher. "Assessing spiritual well-being: Relating with God explains greatest variance in spiritual well-being among Australian youth." International Journal of Children's Spirituality 18 (2013): 306-17. [CrossRef]

62. Sangaroon Jaiwongpab. "Spiritual Health among Relatives of Critically Ill Patients." Master's Thesis, Chiang Mai University, Chiang Mai, Thailand, 2016.

63. Mahdi Esfahani, Ghazali Musa, and Selins Khoo. "The influence of spirituality and physical activity on responsible behaviour and mountaineering satisfaction on Mount Kinabalu, Borneo." Current Issues in Tourism. Published electronically 3 December 2014. [CrossRef]

64. Philé Swanepoel, Karel G.F Esterhuyse, Roelf Beukes, and Nico Nortjé. "Die rol van coping in die verband tussen geestelike welstand en depressive by predikante." HTS Teologiese Studies/Theological Studies. 2012. Available online: http://dx.doi.org/10.4102/hts.v68i1.1071 (accessed on 13 May 2015). 
65. John W. Fisher. "Comparing the influence of God and other Transcendents on spiritual well-being." Religious Education Journal of Australia 30 (2014): 9-15.

66. Craig Ellison. "Spiritual well-being: Conceptualization and measurement." Journal of Psychology E Theology 11 (1983): 330-40.

67. Central Intelligence Agency. "World Fact Book—Religions." 2010. Available online: https://www.cia.gov/ library/publications/the-world-fact-book/religions (accessed on 26 January 2014).

68. Richard H. Schmidt. God Seekers: Twenty Centuries of Christian Spiritualities. Grand Rapids: Wm Eerdmans Publishing Co., 2008.

69. Brian L. Seaward. Health of the Human Spirit: Spiritual Dimensions for Personal Health. Boston: Allyn \& Bacon, 2001.

70. John W. Fisher. "You can't beat relating with God for spiritual well-being: Comparing a generic version with the original spiritual well-being questionnaire called SHALOM." Religions 4 (2013): 325-35. [CrossRef]

71. John Fisher. "Investigating the importance of relating with God for school students' spiritual well-being." Journal of Beliefs \& Values 31 (2010): 325-34. [CrossRef]

72. John W. Fisher. "The importance of relating with God for spiritual well-being." In Spirituality: New Reflections on Theory, Praxis \& Pedagogy. Edited by Michael Weiss and Martin Fowler. Oxford: InterDisciplinary Press, 2012, pp. 147-61.

73. John W. Fisher. "God counts for children's spiritual well-being." International Journal of Children's Spirituality 20 (2015): 191-203. [CrossRef]

74. John Fisher. "Feeling Good, Living Life: A spiritual health measure for young children." Journal of Beliefs $\mathcal{E}$ Values 25 (2004): 307-15. [CrossRef]

75. John Fisher. “Impacting teachers' and students' spiritual well-being." Journal of Beliefs E Values 29 (2008): 252-61. [CrossRef]

76. John W. Fisher, and David J. Brumley. "Nurses' and carers' spiritual well-being in the workplace." Australian Journal of Advanced Nursing 25 (2008): 49-57.

77. John W. Fisher, and David J. Brumley. "Palliative care doctors need help with spiritual well-being." Journal for the Study of Spirituality 2 (2012): 49-60. [CrossRef]

78. Barbara G. Tabachnick, and Linda S. Fidell. Using Multivariate Statistics, 5th ed. Chicago: University of Chicago Press, 2007.

(C) 2016 by the author; licensee MDPI, Basel, Switzerland. This article is an open access article distributed under the terms and conditions of the Creative Commons Attribution (CC-BY) license (http:/ / creativecommons.org/licenses/by/4.0/). 